\title{
The Current State of The Art in Learning Spaces: A Systematic Review Study
}

\author{
$\underline{\text { https://doi.org/10.3991/ijet.v13i11.9247 }}$
}

\author{
Gurhan Durak, Serkan Cankaya $\left({ }^{\varpi}\right)$ \\ Balikesir University, Balikesir, Turkey \\ serkancankaya@balikesir.edu.tr
}

\begin{abstract}
Developments in technology and Internet have brought about different viewpoints and innovations in the field of education as well as in all other areas. In order to meet the expectations of the new generation born into technology and to support new paradigms in learning, the concept of learning spaces has been in use, and it has become an increasingly important concept in related literature. In this respect, the present study aimed at presenting the results of content analysis on the articles related to Learning Spaces concept in Scopus database between 2008 and 2017. A total of 95 papers were examined to determine the concept list, top journal list, most cited papers, research methods and models, participants, data collection tools and variables in these articles. The study is considered to be important as no content analysis has been conducted on the concept of learning spaces concept. The research results revealed a considerable increase in the number of studies on the concept of learning Spaces by year. It was seen in these studies that conceptual/descriptive methods and qualitative methods were prominent as the research methods; that undergraduate students were preferred more as participants; and that the most common data collection tools included interview and questionnaire. Lastly, in the studies examined, perception and academic performance were among the most popular dependent variables.
\end{abstract}

Keywords — content analysis, learning spaces, scopus database, systematic review

\section{Introduction}

Today, it is seen that with the facilities provided by technological developments and with the changes in the labor demand in the market, undergraduate education and postgraduate education given at universities are now in a rapid change [1]. Within the scope of this change, new concepts have occurred, and one of these concepts is learning spaces, which defines new learning environments. Based on the related literature, it could be stated that the concept of "learning spaces" occurred as a result of the historical evolvement of the concepts of "information commons" and "learning commons" [2]. In the concept of information commons, information is important, while in the concept of learning commons, which was influenced by the constructivist theory, learning is prominent. Lastly, for the purpose of defining cooperative seamless learning, the concept of learning spaces occurred. Different from learning commons, the concept of 
learning spaces includes formal and informal learning environments to support learning. Because the word 'space' is a more abstract concept when compared to the word 'place' and because it is used for learning environments, it is also referred to as material spaces and their virtual/digital counterparts [3]. As Oblinger [4] states, "Space whether physical or virtual - can have an impact on learning. It can bring people together; it can encourage exploration, collaboration, and discussion. Or, space can carry an unspoken message of silence and disconnectedness".

The most important feature of learning spaces is said to be spatial designs which encourage and support dynamic, engaged and inspired learning behaviors. A computer laboratory or classroom, which is equipped with latest technologies and which is designed as appropriate to cooperative learning, can be regarded as a learning space, or a dinner accompanied by a large-screen tv set and an activity in which students sitting on grass use their smart phones could both be considered to be learning space [3]. Thus, quite different and flexible learning environments can be created with learning spaces in a way to support the different needs and preferences of different learning communities. In addition, it is reported that learning spaces supported with information technologies have an important place in meeting the expectations of the new generation (the Net Gen) and the new paradigms in learning (constructivist theory, problem based learning, etc.) [5], [6].

\section{$2 \quad$ Related Literature}

This section presents a review of publications that cover learning spaces in a holistic perspective. There are several review studies on the concepts of seamless learning, ubiquitous learning, mobile learning and online learning, which are all interwoven with learning spaces.

In one review study on current trends in the field of distance education research, 861 studies were examined [7]. In this field, the most common keywords were found to be distance education, online learning, e-learning, higher education and distance learning. In the study, social network analysis was conducted on the keywords, and it was seen that concepts such as learning, education, technology, pedagogy, ICT, MOOC, Web2.0, Internet and educational technology were prominent. Most of the studies were found to be designed using the qualitative (47\%) and quantitative (37\%) research methods, and few studies were carried out with the mixed method $(16 \%)$. In the qualitative studies, mostly the research models of case studies (66\%), Design-based research $(9 \%)$, phenomenology $(7 \%)$, action research $(5 \%)$ and grounded theory $(4 \%)$ were used. In the quantitative studies, the research models of survey (58\%), correlational (29\%), experimental $(11 \%)$ and meta-analysis $(2 \%)$ were preferred. In the studies conducted using the mixed method, research models such as exploratory $(55 \%)$, explanatory $(31 \%)$, Convergent parallel ( $8 \%$ ), embedded (4\%) and multiphase (2\%) were used. As for the most frequent data collection tools, they included survey $(\mathrm{N}=194)$, interviews $(\mathrm{N}=128)$, existing artifacts (document analysis) $(\mathrm{N}=59)$ and observations $(\mathrm{N}=17)$. The most popular variables were perception (53), satisfaction (43), gender (39) and interaction (30). In addition, the most common participants were undergraduate students $(31 \%)$, post graduate students $(10 \%)$ and academicians $(10 \%)$. 
In another review study carried out on online discussion in health care education, 14 articles were examined [8]. The results of the review study revealed that content analysis (8), thematic analysis (3), assignment marks/test results (5) and student perceptions of learning (3) were conducted for measurement/analysis purposes. In one study, more than one data collection tool can be used. For instance, among the five quasi-experimental studies, two of them involved use of content analysis on the qualitative data besides pre-test post-test. In addition, 6 studies were carried out with qualitative research design; 5 studies were carried out with quantitative research design; and 3 studies were conducted using the mixed method. Similarly, in another review study on synchronous Online Learning, a total of 157 studies were examined [9]. It was found that of all these studies, 90 of them (57.3\%) were carried out with the qualitative design; 47 (29.9\%) with the group experimental design; $39(24.8 \%)$ with the group nonexperimental design; that 2 of them $(1.3 \%)$ were carried out using the single-case experimental design. The most frequent dependent variables were Perception/Attitude (96), Interaction (71), Achievement (50) and Motivation (6), and the most common data collection tools included Questionnaires (79), Session transcripts (71), Tests (43), Interviews/Focus groups (40), Observations (23) and Task/Product (15). In another review study carried out on e-learning in nursing education, 28 studies were examined [10]. The results demonstrated that of al the studies, 16 of them were designed with the quantitative method; 9 with the mixed method; and 3 of them were conducted using the qualitative method. In addition, the studies were examined under thematic headings such as blended learning, information literacy, nursing Informatics and ICT skills.

In one other review study conducted on Trends and Patterns in Massive Open Online Courses, a total of 362 studies were examined [11]. Among these studies, 53.3\% of them were conceptual/descriptive studies, and the research models of literature reviews (24.3\%), position papers ( $8 \%$ ), opinion papers $(6.1 \%)$ and reports $(5.5 \%)$ were used. In addition, $19.6 \%$ of all the studies were quantitative studies, which involved the use of research models such as survey (12.2\%), correlational (6.1\%) and experimental $(1.7 \%)$. As for the qualitative studies (14.9\%), descriptive (4.1\%), case studies (3\%), and content analysis $(2.2 \%)$ were the most common research models. For the methods of data mining and analytic $(6.1 \%)$, learning analytics $(2.2 \%)$, social network analysis $(1.4 \%)$, text-mining (1.4\%), log analysis $(1.4 \%)$, and Internet and traffic ranks $(0.8 \%)$ were popular research models. In mixed methods studies $(5.5 \%)$, explanatory sequential $(3 \%)$ and convergent parallel $(1.9 \%)$ designs were preferred. As for practice-based studies $(0.6 \%)$, only the action research model was favored.

In another review study on mobile learning, 21 studies carried out between 2005 and 2011 were examined [12]. The results revealed that the focus was mostly on the variables of achievement, productivity, engagement, and motivation. Similarly, in another review study on mobile learning, content analysis was conducted on five articles on mobile technology training for pre-service special education teachers [13]. Of these articles, four of them were carried out with the mixed method, and one of them was carried out with the quantitative research method. As for the data collect tools, questionnaire was used in four articles; open-ended questions were used in three articles, and observations were used in only one article. In addition, all the participants were pre-service teachers. Also, in another review study on mobile learning, 31 studies were 
examined [14]. Among these studies, 13 of them were carried out with the mixed method; 5 with the case study method; 6 with the quantitative method; 3 with the descriptive method; and 3 of them were carried out with the qualitative method. As for the data collection tools used in the studies, questionnaire (26), interviews (13), focus groups (4), literature review (3) and observation (2) were used.

In another review study examining studies carried out on subaqueous learning between 2007 and 2013, seven studies were reached [15]. In these studies, it was seen that the participants were mostly university studies followed by academicians. The most common data collection tools included questionnaires, surveys and assessments, which were followed by semi-structured and group interviews. In all the seven studies, descriptive statistics, statistical analyses and qualitative analyses were applied. In only three of the studies, the mixed method was used besides the qualitative methods. In the studies, the variables included efficacy, cost-effectiveness, satisfaction and usefulness.

In one other study carried out in 2013 and titled "The impact of new learning spaces on teaching practice: Literature Review", a systematic literature review was done in relation to learning spaces [16]. The results revealed that $\mathrm{Bu}$ the most common data collection tools used in these studies carried out on learning spaces were survey, observations, interviews and focus groups. It was seen that most of the studies conducted with the survey method investigated students' perceptions regarding their own behaviors in learning space. It was also found that there were fewer studies on teachers' behaviors in learning space. In the case studies, the focus was more on the design of learning spaces and less on the activities carried out in learning space. A great majority of the studies covered a sample research sample. There were quite a few studies including a large research sample. In most of the studies, the research data were collected regarding the use of learning spaces. It was also found that only a few longitudinal studies tracked teacher perceptions and feedback throughout a more holistic process of innovation.

In another review study on learning spaces, the related studies were examined in three categories: physical, hybrid and virtual. In the category of virtual, the studies were found to be carried out in the fields of learning sciences, computer supported collaborative learning and human-computer interaction [3]. In other words, the studies were related to (1) Pedagogy and curricula and their association to learning space, (2) Learning space design and (3) The development of software tools that create virtual spaces in which students can learn. In addition, the studies revealed that learning spaces had a structure with a dimension of $2 \times 3 \times 3$ (Figure 1).

According to Figure 1, studies on learning spaces can be categorized under 18 dimensions. However, some of the studies found in the category of physical had virtual dimensions, and some of those in the category of virtual had physical dimensions. In another review study on learning spaces and student outcomes, more than 700 printed and online documents from a wide range of sources from peer-reviewed periodicals to websites were examined [17]. The results demonstrated that studies focused more on design and practice and less on processes, preparation, teaming, social interactions, relationships, organizational cultures and leadership. In the studies, the most common variable was achievement, which was followed by personalized needs, social, engagement and learning experience, respectively. 


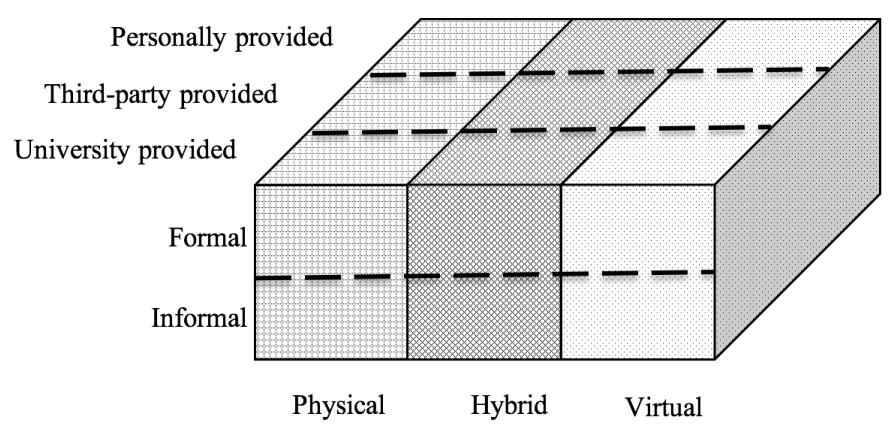

Fig. 1. Three dimensions to the field of research on learning spaces [3]

A large number of studies have been conducted on the concept of Learning Spaces [18], [19]. The fact that hundreds of studies have been indexed on Scopus related to this issue in just three years points to the importance of the concept and shows that it is found quite favorable among researchers. Content analysis is a technique that systematically reaches new results under a specific topic or title, and it could be stated that one of the most important goals in this regard is to reveal the trends in the related subject or field. In this respect, conducting content analysis on such an important concept as Learning Spaces could reveal the current trends in this area and guide researchers willing to conducted research in this field. Accordingly, the primary purpose of the present study was to identify the current trends regarding the concept of Learning Spaces.

\section{Methodology}

In this study, content analysis was conducted on articles found in the database of Scopus regarding the concept of "learning spaces". Content analysis is a "a research method for the subjective interpretation of the content of text data through the systematic classification process of coding and identifying themes or patterns" [20], p.1278. This type of study is considered to be effective in guiding future studies by summarizing a large volume of literature [21], and in this respect, researchers made use of content analysis [22]. As a research method, it represents a systematic and objective tool for describing and quantifying phenomena [23].

The related literature was reviewed considering the following criteria for the articles: being written in English, being published in a reviewed journal and being published in the last 10 years (2008-2017). For the purpose of reaching the related articles, Scopus database was searched. Scopus is the largest abstract and citation database for peerreviewed literature [24], and it lists scientific journals, books and conference proceedings [25]. For the search, 'learning spaces' was used in the 'article title', and various concepts likely to be covered by the concept of 'learning spaces' such as distance education and education technology were used in the 'abstract'. In this way, the purpose was to reach the articles appropriate to the research purpose. The search done on Scopus was as follows: 
(TITLE-ABS-KEY ( \{learning spaces\}) AND TITLE-ABSKEY ( (online learning\} OR \{distance learning\} OR \{distance education\} OR \{educational technology $O R$ \{mobile learning $O R$ \{mlearning $O R$ \{m-learning $O R$ \{elearning OR \{e-learning OR \{web-based OR $\{$ web based\} OR \{instructional technology\} OR \{blended learning\} OR \{virtual learning\} OR \{digital learning\} ) ) AND ( LIMIT-TO ( DOCTYPE, "ar" ) OR LIMIT-TO ( DOCTYPE , "re" ) OR LIMIT-TO ( DOCTYPE, "ip" ) ) AND ( LIMIT-TO ( SUBJAREA, "SOCI" ) OR LIMIT-TO ( SUBJAREA , "COMP" ) ) AND ( LIMIT-TO ( LANGUAGE , "English" ) ) AND ( LIMIT-TO ( PUBYEAR , 2017 ) OR LIMIT-TO ( PUBYEAR , 2016 ) OR LIMIT-TO ( PUBYEAR , 2015 ) OR LIMIT-TO ( PUBYEAR, 2014) OR LIMIT-TO ( PUBYEAR , 2013 ) OR LIMIT-TO ( PUBYEAR , 2012 ) OR LIMIT-TO ( PUBYEAR , 2011 ) OR LIMIT-TO ( PUBYEAR , 2010 ) OR LIMIT-TO ( PUBYEAR , 2009 ) OR LIMIT-TO ( PUBYEAR ，2008） )

As a result of this search, 110 articles were listed. Of all these articles, 103 of them were full-text, and seven articles were excluded from the scope of the present study as they were not reached as full-text articles. As a result, a total of 103 articles were examined in relation to the key words. Consequently, eight articles which were not considered to be directly related to the research purpose of the present study were excluded. The overall research flow is presented in Figure 2.

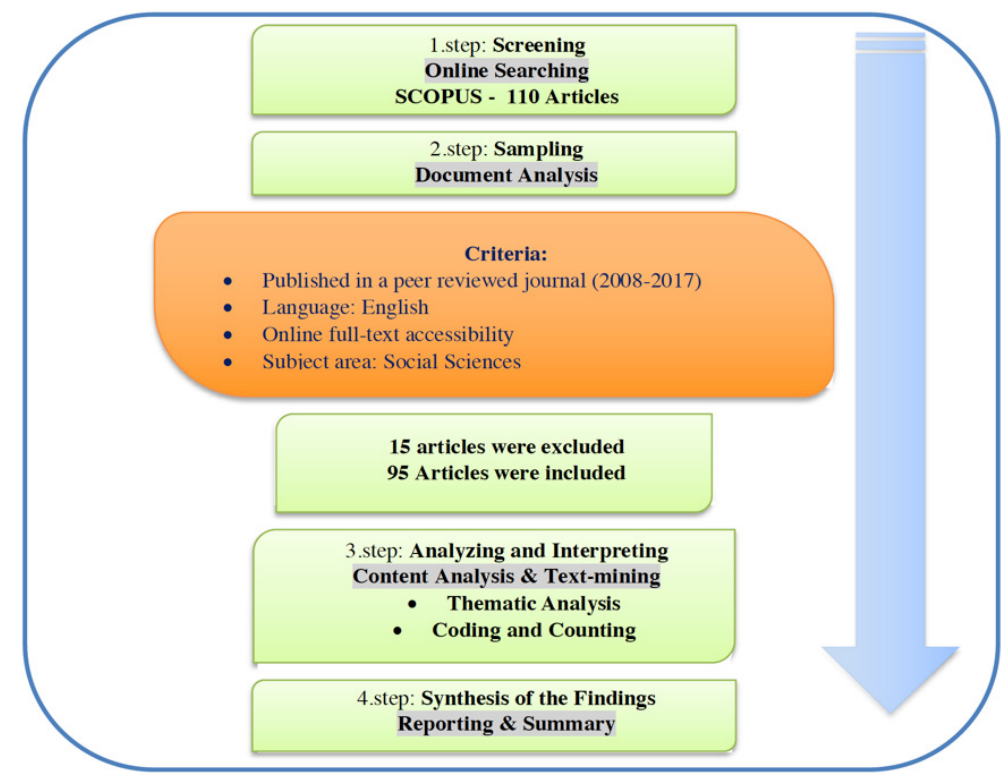

Fig. 2. The overall research flow 
As a result, in the present study, content analysis was conducted on a total of 95 fulltext articles to find answers to the research questions, and the related articles were examined in terms of certain variables. In the study, percentages and frequencies were used to examine the descriptive statistics regarding the variables, participants and data collection tools in the articles. Next, these statistics were interpreted by comparing them with the results of other similar studies in related literature.

\subsection{Reliability}

Based on the previously defined criteria, a table was prepared for the articles reached via the search. The articles were analyzed by two researchers individually, and they noted the results down in their own tables. Next, the tables prepared by the researchers were compared to identify the differences, and the related articles were examined again. Inter-rater reliability of the second-round coding was found to be $\kappa=.895$. Altman [26] suggests that the extent of agreement for Cohen's kappa can be qualified as very good ( 0.81 to 1.00 ). Therefore, the reliability of the first and second raters can be regarded as very good. When consensus was reached on all the findings, the content analysis was finalized.

\section{$4 \quad$ Findings and Discussions}

This section deals with trends in research methods and model/designs, participants, data collection tools, variables, and patterns in keywords in Learning Spaces research. Figure 3 presents the distribution of the 94 articles by year.

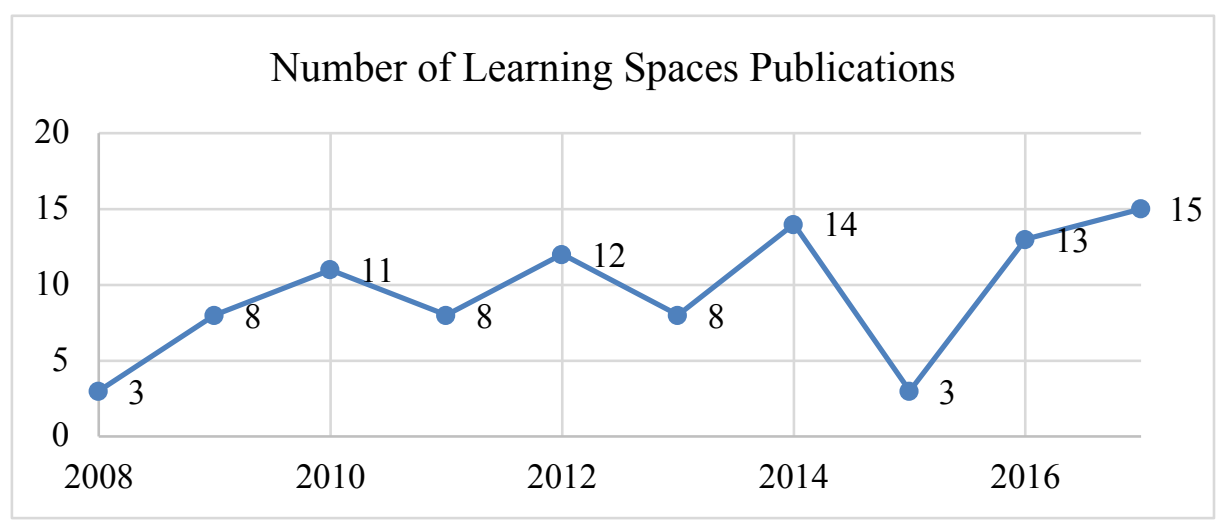

Fig. 3. Figure 3. Number of Publications in Learning Spaces Topic

According to the graph, the highest number of articles belonged to 2017, and there were only three articles in 2015. During the time between 2008 and 2017, it could be stated that the number of articles tended to increase. List of publications with the highest number of citations were given in Table 1 . 
Table 1. List of Authors with the Highest Number of Citations and the Main Focus of the Study

\begin{tabular}{|c|c|c|c|c|c|c|}
\hline Publication Name & $\begin{array}{c}\text { Refer- } \\
\text { ence }\end{array}$ & Year & Journal & $\begin{array}{c}\text { Cited } \\
\text { by }\end{array}$ & $\begin{array}{c}\text { Research } \\
\text { model }\end{array}$ & Main Focus of The Study \\
\hline $\begin{array}{l}\text { Personalized and self- } \\
\text { regulated learning in the } \\
\text { Web } 2.0 \text { era: Interna- } \\
\text { tional exemplars of inno- } \\
\text { vative pedagogy using } \\
\text { social software }\end{array}$ & [27] & 2010 & \begin{tabular}{|l|} 
Australasian \\
Journal of Edu- \\
cational Tech- \\
nology
\end{tabular} & 273 & $\begin{array}{l}\text { Literature } \\
\text { review }\end{array}$ & $\begin{array}{l}\text { Describes emerging prac- } \\
\text { tices with social computing } \\
\text { technologies }\end{array}$ \\
\hline $\begin{array}{l}\text { Leveraging mobile tech- } \\
\text { nology for sustainable } \\
\text { seamless learning: A re- } \\
\text { search agenda }\end{array}$ & {$[6]$.} & 2010 & $\begin{array}{l}\text { British Journal } \\
\text { of Educational } \\
\text { Technology }\end{array}$ & 224 & \begin{tabular}{l|}
$\begin{array}{l}\text { Literature } \\
\text { review }\end{array}$ \\
\end{tabular} & $\begin{array}{l}\text { Review of mobile learning } \\
\text { research for designing seam- } \\
\text { less learning environments }\end{array}$ \\
\hline $\begin{array}{l}\text { Anatomy of a mobilized } \\
\text { lesson: Learning my way }\end{array}$ & [28]. & 2009 & $\begin{array}{l}\text { Computers and } \\
\text { Education }\end{array}$ & 102 & $\begin{array}{l}\text { Case } \\
\text { Study }\end{array}$ & $\begin{array}{l}\text { Introduces mobilized curric- } \\
\text { ula to provide multiple learn- } \\
\text { ing pathways. }\end{array}$ \\
\hline $\begin{array}{l}\text { It's not about seat time: } \\
\text { Blending, flipping, and } \\
\text { efficiency in active learn- } \\
\text { ing classrooms }\end{array}$ & [29] & 2014 & $\begin{array}{l}\text { Computers and } \\
\text { Education }\end{array}$ & 100 & $\begin{array}{l}\text { Experi- } \\
\text { mental }\end{array}$ & $\begin{array}{l}\text { Examines the effect of re- } \\
\text { ducing the seat time in an ac- } \\
\text { tive learning classroom ra- } \\
\text { ther than a traditional amphi- } \\
\text { theater. }\end{array}$ \\
\hline $\begin{array}{l}\text { A learner-centric view of } \\
\text { mobile seamless learning }\end{array}$ & {$[30]$} & 2012 & $\begin{array}{l}\text { British Journal } \\
\text { of Educational } \\
\text { Technology }\end{array}$ & 94 & $\begin{array}{l}\text { Literature } \\
\text { review }\end{array}$ & $\begin{array}{l}\text { Describes learner-centric } \\
\text { view of mobile seamless } \\
\text { learning }\end{array}$ \\
\hline $\begin{array}{l}\text { Students' personal and } \\
\text { social meaning making } \\
\text { in a Chinese idiom mo- } \\
\text { bile learning environ- } \\
\text { ment }\end{array}$ & {$[31]$} & 2010 & \begin{tabular}{|l|} 
Educational \\
Technology and \\
Society
\end{tabular} & 85 & $\begin{array}{l}\text { Design } \\
\text { Based }\end{array}$ & $\begin{array}{l}\text { Presents a design research } \\
\text { study in Mobile Assisted } \\
\text { Language Learning that em- } \\
\text { phasizes learner created con- } \\
\text { tent and contextualized } \\
\text { meaning making. }\end{array}$ \\
\hline \begin{tabular}{|l|} 
Schools going mobile: A \\
study of the adoption of \\
mobile handheld technol- \\
ogies in western Austral- \\
ian independent schools \\
\end{tabular} & {$[32]$} & 2013 & \begin{tabular}{|l|} 
Australasian \\
Journal of Edu- \\
cational Tech- \\
nology
\end{tabular} & 73 & Survey & $\begin{array}{l}\text { Reports a case study about } \\
\text { the adoption of mobile } \\
\text { handheld technologies. }\end{array}$ \\
\hline $\begin{array}{l}\text { A time-based blended } \\
\text { learning model }\end{array}$ & [33] & 2011 & On the Horizon & 69 & $\begin{array}{l}\text { Opinion } \\
\text { Paper }\end{array}$ & $\begin{array}{l}\text { Seeks to outline a time- } \\
\text { based strategy for blended } \\
\text { learning in synchronous and } \\
\text { asynchronous modalities. }\end{array}$ \\
\hline \begin{tabular}{|l|} 
Space matters: The im- \\
pact of formal learning \\
environments on student \\
learning
\end{tabular} & [34] & 2011 & $\begin{array}{l}\text { British Journal } \\
\text { of Educational } \\
\text { Technology }\end{array}$ & 60 & $\begin{array}{l}\text { Experi- } \\
\text { mental }\end{array}$ & $\begin{array}{l}\text { Identifies the relationship } \\
\text { between formal learning } \\
\text { spaces and student learning } \\
\text { outcomes. }\end{array}$ \\
\hline $\begin{array}{l}\text { Mobile learning: At the } \\
\text { tipping point }\end{array}$ & {$[35]$} & 2011 & $\begin{array}{l}\text { Turkish Online } \\
\text { Journal of Edu- } \\
\text { cational Tech- } \\
\text { nology }\end{array}$ & 54 & $\begin{array}{l}\text { Literature } \\
\text { review }\end{array}$ & $\begin{array}{l}\text { Explores the use of simula- } \\
\text { tions and virtual environ- } \\
\text { ments to build learning } \\
\text { spaces that provide connec- } \\
\text { tions to students globally }\end{array}$ \\
\hline
\end{tabular}


When Table 1 is examined, it is seen that almost half of the articles cited most were literature reviews conducted with the Conceptual/Descriptive methods. Based on this situation, it could be stated that the researchers benefitted more from the review studies which summarized the studies in related literature and which presented these studies in a systematic manner. Researchers who want to carry out studies on the related research topic can save time by getting informed more about the related literature by making use of such review studies. Also, in the study, the journals where the articles were published were examined. The results can be seen in Figure 4.

\section{Number of Publications}

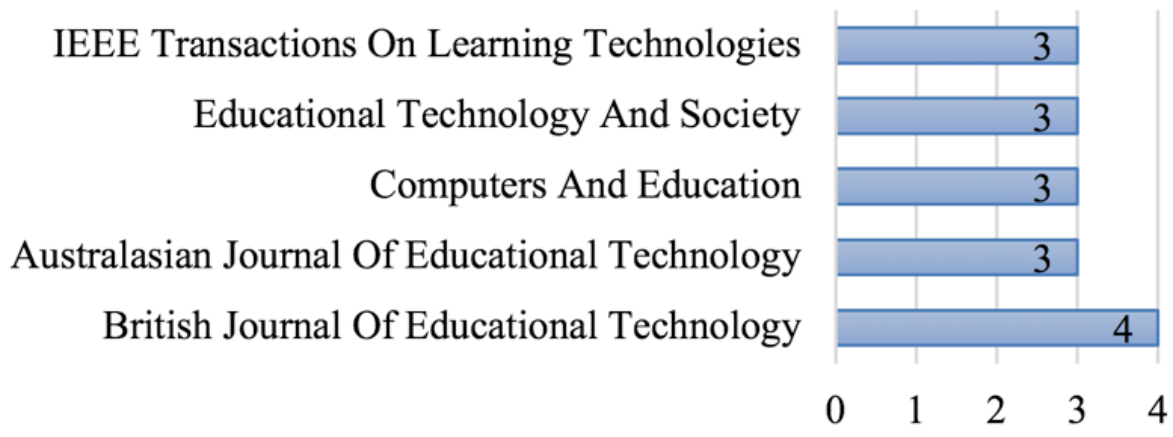

Fig. 4. Journals Reviewed Articles Published

Accordingly, the first five journals where the articles were published most included British Journal of Educational Technology, Computers \& Education, Australasian Journal of Educational Technology, Educational Technology and Society and IEEE Transactions on Learning Technologies.

\subsection{Keyword Analysis}

Figure 5 depicts the major topics covered in the selected articles published between 2008 and 2017. Figure 5 presents the relationships regarding the keywords used in the studies. When the frequencies of the keywords in the articles were examined, it was seen that concepts such as "higher education", "blended learning", "e-learning", "mobile learning" and "collaborative learning" were prominent. This graph could be said to be explanatory enough to reveal the relationships between the keywords. Keywords such as e-learning, online learning, distance education and higher education, which are among the basic concepts in this field, are consistent with the findings obtained by Bozkurt et al [7]. Different from Bozkurt et al., it is seen in the present study that the concept of learning spaces was prominent. 


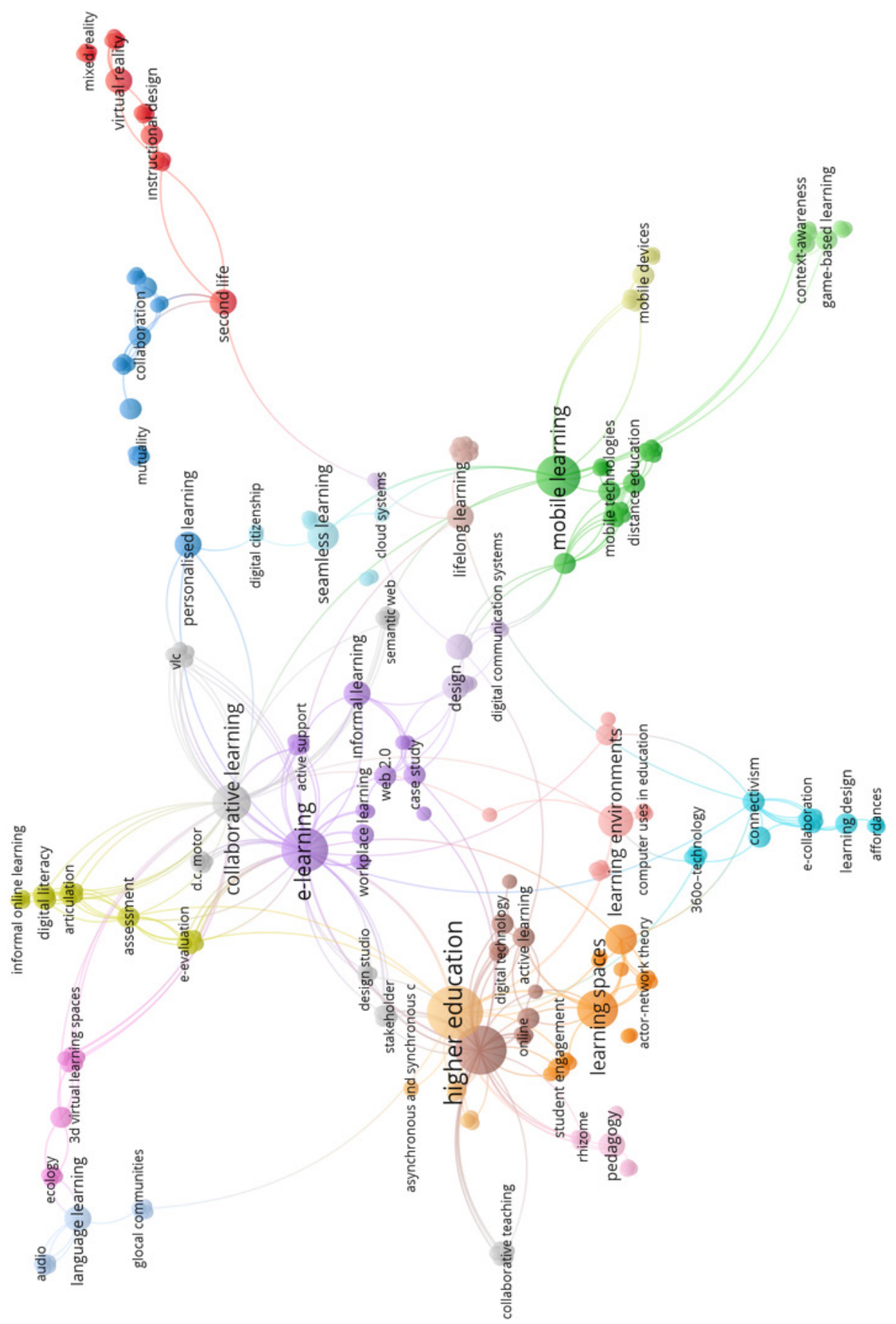

Fig. 5. Major Topics Covered 


\subsection{Participants}

Table 2 presents the frequencies and percentages regarding the participants in the articles examined within the scope of the present study.

Table 2. Participants

\begin{tabular}{|l|c|c|c|}
\hline \multicolumn{1}{|c|}{ Participants } & Frequency & Percentage & Sample Size \\
\hline Undergraduate students & 30 & 46,15 & $2-1000$ \\
\hline Academicians & 10 & 15,38 & $2-85$ \\
\hline K-12 Students & 7 & 10,77 & $3-305$ \\
\hline K-12 Teachers & 5 & 7,69 & $1-91$ \\
\hline Documents & 4 & 6,15 & $69-96$ \\
\hline Phd students & 2 & 3,08 & $16-34$ \\
\hline specialist & 2 & 3,08 & $4-13$ \\
\hline adults & 3 & 4,62 & $1-343$ \\
\hline masters students & 1 & 1,54 & 53 \\
\hline K-12 Managers & 1 & 1,54 & 10 \\
\hline
\end{tabular}

*One study may employ more than one target group

When the data presented in Table 2 are examined, it is seen that undergraduate students $(\mathrm{N}=30)$, Academicians $(\mathrm{N}=10)$ and $\mathrm{K}-12$ students $(\mathrm{N}=7)$ were in the first three places and that these groups constituted approximately $71 \%$ of all the participants. When the sample sizes were examined, it was seen that there were minimum two and maximum 1000 learners as undergraduate students; that the number of learners ranged between 2 and 85 for academicians; and there were minimum 17 and maximum 2748 learners as K-12 students. The fact that undergraduate students were favored more as participants is parallel to the findings of other related studies in literature [7], [13], [15].

\subsection{Data Collection Tools}

Table 3 presents frequencies and percentages regarding the data collection tools used in the articles examined within the scope of the study.

Table 3. Data Collection Tools

\begin{tabular}{|l|c|c|}
\hline \multicolumn{1}{|c|}{ Data Collection Tools } & Frequency & Percentage \\
\hline Interview & 24 & 22,86 \\
\hline Questionnaire & 23 & 21,9 \\
\hline Scale & 14 & 13,33 \\
\hline Observation & 11 & 10,48 \\
\hline Focus group & 8 & 7,62 \\
\hline Pre-test post-test & 7 & 6,67 \\
\hline Discussion post & 7 & 6,67 \\
\hline Document analysis & 5 & 4,76 \\
\hline Field notes & 4 & 3,81 \\
\hline Log & 2 & 1,9 \\
\hline
\end{tabular}

*One study may employ more than one data collection tools 
According to Table 3, as the most popular data collection tools, interview (22,9\%), questionnaire $(21,9 \%)$ and scale $(13,3 \%)$ were the most frequent ones used in these studies. The fact that interview and questionnaire were the most common data collection tools is also supported by other research results in related literature [7], [9], [13][16].

\subsection{Variables/Research Interests}

The articles were categorized with respect to the dependent variables. Table 4 presents the related frequencies and percentages.

Table 4. Variables / Research Interests

\begin{tabular}{|l|c|c|l|c|c|}
\hline \multicolumn{1}{|c|}{ Dependent Variables } & f & $\mathbf{\%}$ & \multicolumn{1}{|c|}{ Dependent Variables } & f & \% \\
\hline Perception & 12 & 18,75 & Experience & 3 & 4,69 \\
\hline Academic-performance & 9 & 14,06 & Social Skills & 1 & 1,56 \\
\hline opinion & 8 & 12,5 & Design & 1 & 1,56 \\
\hline engagement & 6 & 9,38 & Awareness & 1 & 1,56 \\
\hline Motivation & 5 & 7,81 & Adaptation & 1 & 1,56 \\
\hline Self-efficacy & 4 & 6,25 & social connectedness & 1 & 1,56 \\
\hline Satisfaction & 3 & 4,69 & social capital & 1 & 1,56 \\
\hline Interaction & 3 & 4,69 & behavior & 1 & 1,56 \\
\hline Attitude & 3 & 4,69 & usability & 1 & 1,56 \\
\hline
\end{tabular}

According to Table 4, the most frequent dependent variable was "perception" $(18,7$ $\%$ ) used in 12 studies. $(37,7 \%)$ used in 26 studies. This variable was followed by "academic-performance" (14\%) in 9 studies, "opinion" (12,5\%) in 8 studies, "engagement" $(9,4 \%)$ and "motivation" $(7,8 \%)$. It was seen that the most frequent dependent variables used in the articles were perception, academic performance and opinion, and they constituted almost half of all the variables. This result is similar to the findings of other studies carried out by Bozkurt et al. [7], Martin et al. [9] and Hall [16].

\subsection{Research Method and Design}

An analysis of the findings about Research Method and Design was presented in Table 5. The analysis reveals that researchers mostly preferred Conceptual/Descriptive methods $(38 \%)$, while report papers $(n=13)$, opinion paper $(n=11)$, literature review $(\mathrm{n}=9)$ were the most frequent ones used in Conceptual/Descriptive methods. Qualitative methods $(36 \%)$ were the second most preferred research paradigm, and among these studies, case studies $(n=27)$ and content analysis $(n=2)$ were the most common in these researches. Quantitative method studies scored the next highest (14\%), within which experimental studies $(n=8)$ and survey $(n=4)$ were the most frequent ones used in Quantitative methods. Mixed methods (11\%) were the fourth most preferred research paradigm, within which explanatory sequential $(n=5)$ and convergent parallel were the leading research models. Finally, it was revealed that practice-based research methods $(2 \%)$ 
following design-based research $(\mathrm{n}=2)$ approaches were the least preferred method. In the sampled publications, none of the studies used data mining or analytical methods. The most popular research methods and models were different in different review studies. In this study, the most common ones were Conceptual/Descriptive methods. On the other hand, in some studies, mixed methods [13], [14] were popular, while in some other studies, quantitative methods [10], [15] were more common, and still in some other studies, qualitative methods [7]-[9] were favored more. Similar to the related finding obtained in the present study, in one review study carried out by Bozkurt et al. [11], Conceptual/Descriptive methods were used more. Thus, it could be stated that in recent studies, Conceptual/Descriptive methods have become more popular.

Table 5. Frequencies of Methods and Models/Designs

\begin{tabular}{|c|c|c|c|c|c|c|}
\hline Method & f & $\%$ & Model/Design & $\mathrm{f}$ & $\%$ CUM & $\%$ TOTAL \\
\hline \multirow{5}{*}{ Quantative } & \multirow{5}{*}{12} & \multirow{5}{*}{14} & Survey & 4 & 33 & 7 \\
\hline & & & Experimental & 8 & 68 & 15 \\
\hline & & & Causal Comparative & 0 & 0 & 0 \\
\hline & & & Correlational & 0 & 0 & 0 \\
\hline & & & Meta-analysis & 0 & 0 & 0 \\
\hline \multirow{9}{*}{ Qualitative } & \multirow{9}{*}{34} & \multirow{9}{*}{36} & Case Study & 27 & 84 & 49 \\
\hline & & & Content Analysis & 2 & 6 & 2 \\
\hline & & & Etnography & 0 & 0 & 0 \\
\hline & & & Descriptive & 1 & 3 & 1 \\
\hline & & & Phenomenology & 1 & 3 & 1 \\
\hline & & & Grounded Theory & 1 & 3 & 1 \\
\hline & & & Meta-synthesis & 0 & 0 & 0 \\
\hline & & & Historical & 0 & 0 & 0 \\
\hline & & & Heuristic & 0 & 0 & 0 \\
\hline \multirow{6}{*}{ Mixed } & \multirow{6}{*}{10} & \multirow{6}{*}{11} & Explanatory sequential & 5 & 51 & 9 \\
\hline & & & Embedded & 1 & 10 & 2 \\
\hline & & & Convergent Parallel & 4 & 40 & 7 \\
\hline & & & Exploratory Sequential & 0 & 0 & 0 \\
\hline & & & Multiphase & 0 & 0 & 0 \\
\hline & & & Transformative & 0 & 0 & 0 \\
\hline \multirow{9}{*}{$\begin{array}{c}\text { Conceptual/Descriptive } \\
\text { /Other }\end{array}$} & \multirow{9}{*}{36} & \multirow{9}{*}{38} & Opinion Paper & 11 & 31 & $\square \quad 20$ \\
\hline & & & Literature Review & 9 & $\square \quad 26$ & $\square \quad 16$ \\
\hline & & & Report & 13 & 37 & 23 \\
\hline & & & Reflection Paper & 1 & 3 & 2 \\
\hline & & & Comparative & 1 & 3 & 2 \\
\hline & & & Technical Paper & 0 & 0 & 0 \\
\hline & & & Position Paper & 0 & 0 & 0 \\
\hline & & & Field Notes & 0 & 0 & 0 \\
\hline & & & Systematic Review & 1 & 3 & 2 \\
\hline \multirow{2}{*}{ Practice Based } & \multirow{2}{*}{2} & \multirow{2}{*}{2} & Design Based Research & 2 & 6 & 4 \\
\hline & & & Action Research & 0 & 100 & 0 \\
\hline \multirow{6}{*}{ Data Mining and Analysis } & \multirow{6}{*}{0} & \multirow{6}{*}{0} & Learning Analytics & 0 & 0 & 0 \\
\hline & & & Social Network Analysis & 0 & 0 & 0 \\
\hline & & & Text Mining & 0 & 0 & 0 \\
\hline & & & Log Analysis & 0 & 0 & 0 \\
\hline & & & Internet and Traffic Ranks & 0 & 0 & 0 \\
\hline & & & Sentiment Analysis & 0 & 0 & 0 \\
\hline
\end{tabular}




\section{Conclusion and Future Research Directions}

In a content analysis, this study explored 95 publications to identify trends and patterns in Learning Spaces concept. The findings revealed that from 2016 to 2017, an increasing interest was witnessed in Learning Spaces concept, as well as an apparent positive trend, which means that the number of publications that cover this concept will continue to increase.

When the 95 articles were taken into account with respect to their research methods and models, it was seen that Conceptual/Descriptive methods and Qualitative methods were prominent. The Quantitative methods constituted 14\% of all the methods. This result was surprising as experimental methods are not much favored in studies carried out on concepts like online learning and technology, which are closely related to the concept of Learning Spaces. The journals where the studies were published most were found to include British Journal of Educational Technology, Computers \& Education, Australasian Journal of Educational Technology, Educational Technology and Society and IEEE Transactions on Learning Technologies. Based on this, it could be stated that the concept of learning spaces can be associated more with the field of educational technology. The studies related to the concept of Learning Spaces were examined with respect to their being cited. When the first ten studies in the list were examined, it was seen that the methods used in almost half of them were literature review research models found under the category of Conceptual/Descriptive methods. Accordingly, it could be stated that the researchers made use of such studies which summarized the studies in related literature and which presented these studies in a systematic way. The present study, which was designed as content analysis, is thought to be a study which will guide researchers who will study on the concept of Learning Spaces. As a result of the analysis of the keywords, it was seen that they mostly included higher education, blended learning, e-learning, mobile learning and collaborative learning. Considering the fact that the common point of these concepts was distance education, the concept of Learning Spaces could be said to be interwoven with distance education and with other related sub-concepts. In the articles examined in the study, it was seen that almost half of the participants were undergraduate students. This result could be explained with the fact that it is easier to conduct studies with undergraduate students. When examined in terms of the data collection tools used, interview and questionnaire were dominant. This situation could be explained with the fact that conceptual /descriptive and qualitative methods were prominent research methods.

As demonstrated by the review of the related literature, there isn't any content analysis conducted to Learning Spaces concept. Therefore, the present study is expected to be a pioneering one. Based on the findings of this research, the following suggestions can be considered for future study directions:

- Researchers who plan to conduct studies on the concept of Learning Spaces may use dependent variables which were used less frequently in previous studies. In this way, instead of conducting similar studies, maximum variety can be obtained regarding the related concept. 
- Several different variables (country, language, article, thesis, etc.) can be compared thanks to content analyses conducted on extensive sampling.

- There is a need for gender studies particular focusing on the gender imbalance in Learning Spaces concept.

- When the articles examined in the present study were taken into account with respect to the methods used, it was seen that mixed methods ranked fourth. However, increasing the number of mixed studies, which make use of advantages of both qualitative and quantitative methods, could allow gather more in-depth data in the related field.

- Finally, Learning Spaces practices may benefit more from online learning environments, and analysis of such practices through data mining and analytical approaches may produce effective and efficient research findings.

\section{$6 \quad$ References}

[1] A. Sonmez, L. Gocmez, D. Uygun, and M. Ataizi, "A review of current studies of mobile learning," J. Educ. Technol. Online Learn., vol. 1, no. 1, pp. 13-27, 2018. https://doi.org/10.31681/jetol.378241

[2] A. Turner, B. Welch, and S. Reynolds, "Learning spaces in academic libraries - A review of the evolving trends," Australian Academic and Research Libraries, vol. 44, no. 4. Taylor \& Francis, pp. 226-234, 2013.

[3] R. A. Ellis and P. Goodyear, "Models of learning space: integrating research on space, place and learning in higher education," Rev. Educ., vol. 4, no. 2, pp. 149-191, 2016. https://doi.org/10.1002/rev3.3056

[4] D. G. Oblinger, Learning Spaces. Louisville, CO: Educause, 2006.

[5] M. Brown, "Learning spaces," in Educating the Net Generation, D. G. Oblinger and J. L. Oblinger, Eds. Boulder, Colorado: Educause, 2006, pp. 1-444.

[6] C. K. Looi, P. Seow, B. Zhang, H. J. So, W. Chen, and L. H. Wong, "Leveraging mobile technology for sustainable seamless learning: A research agenda," Br. J. Educ. Technol., vol. 41, no. 2, pp. 154-169, 2010. https://doi.org/10.1111/j.1467-8535.2008.00912.x

[7] A. Bozkurt, E. A. Ozbek, S. Yilmazel, E. Erdogdu, H. Ucar, and E. Guler, "Trends in distance education research: A content analysis of journals 2009 -2013," Int. Rev. Res. Open Distrubted Learn., vol. 16, no. 1, pp. 1-19, 2015. https://doi.org/10.19173/irrodl.v16i1.1953

[8] J. Thomas, "Exploring the use of asynchronous online discussion in health care education: A literature review," Comput. Educ., vol. 69, pp. 199-215, 2013. https://doi.org/10.1016/ j.compedu.2013.07.005

[9] F. Martin, L. Ahlgrim-Delzell, and K. Budhrani, "Systematic review of two decades (1995 to 2014) of research on synchronous online learning," Am. J. Distance Educ., vol. 31, no. 1, pp. 3-19, 2017. https://doi.org/10.1080/08923647.2017.1264807

[10] D. Button, A. Harrington, and I. Belan, "E-learning \& information communication technology (ICT) in nursing education: A review of the literature," Nurse Educ. Today, vol. 34, no. 10, pp. 1311-1323, 2014. https://doi.org/10.1016/j.nedt.2013.05.002

[11] A. Bozkurt, E. Akgün-Özbek, and O. Zawacki-Richter, "Trends and patterns in massive open online courses: Review and content analysis of research on MOOCs (2008-2015)," Int. Rev. Res. Open Distrib. Learn., vol. 18, no. 5, pp. 118-147, 2017. https://doi.org/10.19173/ irrodl.v18i5.3080 
[12] P. Pollara and K. K. Broussard, "Mobile technology and student learning: What does current research reveal?," Int. J. Mob. Blended Learn., vol. 3, no. 3, pp. 34-42, 2011. https://doi.org/10.4018/jmbl.2011070103

[13] L. Balderaz and K. Rosenblatt, "Preparing special educators to use mobile technology: A review of the literature," Interact. Des. Archit. J., vol. 28, pp. 34-48, 2016.

[14] R. Kaliisa and M. Picard, "A systematic review on mobile learning in higher education: The African perspective," Turkish Online J. Educ. Technol., vol. 16, no. 1, pp. 1-18, 2017.

[15] M. A. Virtanen, E. Haavisto, E. Liikanen, and M. Kääriäinen, "Ubiquitous learning environments in higher education: A scoping literature review," Educ. Inf. Technol., vol. 23, no. 2, pp. 985-998, 2018. https://doi.org/10.1007/s10639-017-9646-6

[16] C. Hall, "The impact of new learning spaces on teaching practice: Literature review," Academic Development Group, College of Business, RMIT University, Melbourne, Vic, 2013.

[17] J. Blackmore, D. Bateman, J. Loughlin, J. O'Mara, and G. Aranda, "Research into the connection between built learning spaces and student outcomes: Literature review," Department of Education and Early Childhood Development, East Melbourne, Vic, 2011.

[18] A. Harrison and L. Hutton, Design for the changing educational landscape: Space, place and the future of learning. New York, NY: Routledge, 2013. https://doi.org/10.4324/9780 203762653

[19] P. Temple, "Learning spaces in higher education: An under-researched topic," London Rev. Educ., vol. 6, no. 3, pp. 229-241, 2008. https://doi.org/10.1080/14748460802489363

[20] H. F. Hsieh and S. E. Shannon, "Three approaches to qualitative content analysis," Qual. Health Res., vol. 15, no. 9, pp. 1277-1288, 2005. https://doi.org/10.1177/1049732 305276687

[21] M. Petticrew and H. Roberts, Systematic Reviews in the Social Sciences: A Practical Guide. Malden, MA: Blackwell Publishing Ltd, 2006. https://doi.org/10.1002/9780470754887

[22] V. Wilson, "Research methods: Content analysis," Evid. Based Libr. Inf. Pract., vol. 6, no. 4, pp. 177-179, 2011. https://doi.org/10.18438/B86P6S

[23] M. Schreier, Qualitative Content Analysis in Practice. Thousand Oaks, CA: Sage, 2012.

[24] E. Buyukkol Kose, G. Cetin, and E. Yunkul, "A content analysis of studies related to educational technologies in biology education," J. Educ. Technol. Online Learn., vol. 1, no. 2, pp. 1-15, 2018. https://doi.org/10.31681/jetol.419932

[25] Scopus, "The world of scientific research is more demanding than ever before," 2018. [Online]. Available: https://www.elsevier.com/solutions/scopus. [Accessed: 18-Jul-2018].

[26] D. G. Altman, Practical Statistics for Medical Research. London: CRC Press, 1990.

[27] C. McLoughlin and M. J. W. Lee, "Personalised and self regulated learning in the Web 2.0 era: International exemplars of innovative pedagogy using social software," Australas. J. Educ. Technol., vol. 26, no. 1, pp. 28-43, 2010. https://doi.org/10.14742/ajet.1100

[28] C. K. Looi, L. H. Wong, H. J. So, P. Seow, Y. Toh, W. Chen, B. Zhang, C. Norris, and E. Soloway, "Anatomy of a mobilized lesson: Learning my way," Comput. Educ., vol. 53, no. 4, pp. 1120-1132, 2009. https://doi.org/10.1016/j.compedu.2009.05.021

[29] P. Baepler, J. D. Walker, and M. Driessen, "It's not about seat time: Blending, flipping, and efficiency in active learning classrooms," Comput. Educ., vol. 78, pp. 227-236, 2014. https://doi.org/10.1016/j.compedu.2014.06.006

[30] L. H. Wong, "A learner-centric view of mobile seamless learning," Br. J. Educ. Technol., vol. 43, no. 1, pp. 19-23, 2012. https://doi.org/10.1111/j.1467-8535.2011.01245.x

[31] L. H. Wong, C. K. Chin, C. L. Tan, and M. Liu, "Students' personal and social meaning making in a Chinese idiom mobile learning environment," Educ. Technol. Soc., vol. 13, no. 4, pp. 15-26, 2010. 
[32] M. Pegrum, G. Oakley, and R. Faulkner, "Schools going mobile: A study of the adoption of mobile handheld technologies in western australian independent schools," Australas. J. Educ. Technol., vol. 29, no. 1, pp. 66-81, 2013. https://doi.org/10.14742/ajet.64

[33] A. Norberg, C. D. Dziuban, and P. D. Moskal, "A time-based blended learning model," Horiz., vol. 19, no. 3, pp. 207-216, 2011. https://doi.org/10.1108/10748121111163913

[34] D. C. Brooks, "Space matters: The impact of formal learning environments on student learning," Br. J. Educ. Technol., vol. 42, no. 5, pp. 719-726, 2011. https://doi.org/10.1111/j.14678535.2010.01098.x

[35] T. Franklin, "Mobile learning : At the tipping point," Turkish Online J. Educ. Technol., vol. 10, no. 4, pp. 261-275, 2011.

\section{$7 \quad$ Authors}

Gurhan Durak is Assistant Professor of Computer Education and Instructional Technology at Balikesir University. Dr. Durak gained his Ph.D. in Distance Education at Anadolu University at December, 2013. His academic interest areas are open and distance learning, social learning networks, support services in distance education, online learning and administration of distance education He has over than 20 journal articles published in international indexes, 1 international book chapter and other national and international articles, papers submitted to international meetings.

Serkan Cankaya is Assistant Professor of Computer Education and Instructional Technology at Balikesir University. Dr. Cankaya received his BA in Computer Education Department at Middle East Technical University and MS in Computer Education \& Instructional Technology Department at Balıkesir University. He gained his Ph.D. in Computer Education \& Instructional Technology Department at Anadolu University at June, 2013. His academic interest areas are social learning networks, educational multimedia, open and distance learning, online learning and special educational technology. He has journal articles published in international indexes, book chapters, papers submitted to international meetings.

Article submitted 18 July 2018. Resubmitted 27 August 2018. Final acceptance 07 September 2018. Final version published as submitted by the authors. 